International Journal of Community and Cooperative Studies

Vol.8 No.1, pp.1-8, June 2020

Published by ECRTD- UK

ISSN 2057-2611(Print), ISSN 2057-262X(Online)

\title{
THE EFFECT OF FINANCIAL OUTREACH, ON THE FINANCIAL SUSTAINABILITY OF SAVING AND CREDIT COOPERATIVE UNIONS: THE CASE OF OROMIA NATIONAL REGIONAL STATE OF ETHIOPIA
}

\author{
Mr. Berhanu Bayisa Eticha \\ PhD Scholar; Institute of Cooperatives and Development studies, Department Cooperative; Ambo, \\ Ethiopia, Mobile: +251913260575 \\ Dr. Workineh Abebe \\ Lecturer at Ambo University; Institute of Cooperatives and Development Studies, Department of \\ Development Studies, Ambo, Ethiopia
}

\begin{abstract}
The objective of this study is $h$ to analyse the effect of financial outreach, on financial sustainability of SACCO Unions in Oromia national regional state of Ethiopia. Descriptive research design applied in which involved the collection of longitudinal audited financial and administration data of sampled unions for the period of ten years from 2008 to 2017. The Number of Primary Members (NPM) and the Total Saving Mobilized (TSM) independent variables were used to analyze the effect of breadth of outreach on financial sustainability of unions in the region. Both independent variables have significant effect on the financial sustainability of Unions in the region. The data collected was analyzed using descriptive statistics and multiple regressions model to evaluate the effect of independent variables on dependent variables. Both the number of primary societies and total saving mobilization has significant on financial sustainabilties of unions. However, the number of primary Saccos emanated to membership and total saving mobilized by unions were insignificant as compared to total primary societies and potential in the region. Most unions have limited outreach, dependent to external sources of fund rather than internal resource mobilization, high cost of funds; unions are not open for new Sacco's membership, imbalanced demand of loan seekers and savers. As a result, the sustainability status of the SACCO unions in the region indicates $48 \%$. While the rest $52 \%$ of them are in danger to failure. By this study, we recommend that the Unions should open their door to accept the membership of primary Saccos and prepare strategy for saving mobilization rather than dependent on external financial sources. The cooperative promotion office needs to have strong financial and operational regulations that guides the outreach and financial sustainability of the unions accordingly.
\end{abstract}

KEYWORDS: SACCO unions, financial sustainability, financial outreach

\section{INTRODUCTION}

Savings and Credit Cooperative Societies are voluntary associations of people who come together with the common goal of encouraging savings and granting credit to members in order to improve their livelihoods SACCOs are owned and democratically controlled by their members (Matumo, Maina, \& Jorge, 2013; Moturi \& Mbiwa, 2015). Ethiopian cooperative proclamation No. 985/2016, defined it as "cooperative society" means an autonomous association having legal personality and democratically controlled by persons united voluntarily to meet their common economic, social and 
International Journal of Community and Cooperative Studies

Vol.8 No.1, pp.1-8, June 2020

Published by ECRTD- UK

ISSN 2057-2611(Print), ISSN 2057-262X(Online)

cultural needs and other aspirations, which could not addressed individually,". Primary cooperative society" means a cooperative society established by individuals having similar interest and objective with minimum number of members prescribed in this Proclamation to produce, provide service to engage in both activities. While cooperative societies union" means a secondary level cooperative society established by primary cooperative societies having similar objective with a minimum number of members as prescribed in the Proclamation to produce, provide service or to engage in both activities that are beyond the capacity of primary cooperative societies. Therefore, SACCO Unions are form of financial institution that provides services to primary members. Doing so, Unions play positive role in reducing poverty, increasing investment, creating employment and contributing to economic development at micro and macro levels. Sacco's unions are tool, which facilitates financial and social inclusion, improving the lively hoods of members, enhancing their saving behavior and empowering them. Financial cooperatives (primary and secondary SACCOs) in Ethiopia are valuable institutions that improve the lively hoods of millions of people, buildup large amounts of resources in the form of saving and provide affordable loans at friendly terms. The main purposes of SACCO unions are financial intermediation and investment. Financial intermediation entails encouraging and promoting thrift culture of saving among members; educating members on how to create assets, acquire collateral for loan access and create an enabling environment for the flow of funds in the community; and making finance available to members (Moturi \& Mbiwa, 2015). The investment function involves encouraging members to develop formal businesses, advising members to buy valuable shares, and paying dividends to members at the end of the financial year. To achieve these objectives, unions accept savings from their members and encourage them to borrow, inspire them to invest in income generating activities, which then makes a profit (Okibo \& Chepkwei, 2013).

\section{Historical Development of SACCOs}

According to Federal cooperative agency report of (2019), despite the difficulties experienced, SACCO's movement in Ethiopia had registered numerical growth over the past decade in terms of both number of members, saving mobilized and capital acquired, however, membership was still much smaller towards the huge potential. As empirical literature reviewed suggested, for the past decade, Ethiopia has experienced positive trend in the growth of both primary and secondary saving and credit cooperative societies (FCA 2015, Page.4). Such a constructive growth movement provides a hopeful future way for improved access financial services, which in turn promotes resource Mobilization, Access of finance, encouraging investment, asset accumulation, and stimulating economic activities at grass root level, and help the urban and rural poor uplift from poverty (Kifle Tesfamariam, 2012). In 2016, there were reportedly 126 SACCO Unions and 19,788 primary Saving and credit cooperatives societies, representing individual members of 4,180,330; of which 2,476,330 are male and 1,704,000 were female (FCA annual report 2016). SACCOs have been constantly growing in terms of numbers growth, saving mobilized and capital mobilized over the period and contributing $4.29 \%$ to the National Domestic Saving.

According to Oromia Cooperative Promotion Agency, there are total 20,159 primary cooperatives having capital of birr 3,968,236. From the mentioned number of primary cooperatives 3,400 are nonactive or not performing well. These depicted that more than $17 \%$ of total primary cooperatives are vanished within the past ten years. From the total primary cooperatives mentioned above 8,130 are 
International Journal of Community and Cooperative Studies

Vol.8 No.1, pp.1-8, June 2020

Published by ECRTD- UK

ISSN 2057-2611(Print), ISSN 2057-262X(Online)

primary SACCOs, which account $40 \%$ of the whole cooperatives in the region. From the mentioned number of primary SACCOs 1,177 /14.5\% of them are not active or are not operational.

There are total 130 registered unions (including Sacco Unions) in the region; of which 20 / (19.23\%) were not factional and exist in name only within the past ten years. In addition, from 28 total SACCO Unions registered in the region, five of them were not active or not operational. As a result, 23 active Unions having 1,535 primary member societies for the past ten years. This indicate that from active registered 6,953 primary SACCOs only 1,535 were came to the membership of Sacco unions. This indicates that the unions had mobilized only $22 \%$ of the total primary Saccos registered in the region. While the rest, $(5,418)$ or $88 \%$ were not came to Union's membership. As data from the region coop promotion office (2019), primary SACCOs had Mobilized Individual Member 1,026,293, Capital of birr 1,096,521,892 and savings birr 1, 6227, 722,942.97 respectively. While unions reached 1,535 primary Saccos (having 225, 784 individual members), capital of birr 57,606,207 and saving 1, 396, $128,86.5$ respectively. This indicates that unions mobilized (outreached) to only $2.2 \%$ of individual members of primary Saccos. They also Collected $0.525 \%$ of total capital and mobilized $8.57 \%$ of saving compared to primary society in the region. From this fact, we understand that how far the unions have gone to outreach the targeted community need their financial intermediation. That is why the researchers concerned to investigate the effect of outreach (financial breadth) on financial sustainability of Sacco unions in the region.

\section{Common Challenges of Financial Cooperatives}

Saving and credit cooperatives and Unions in Ethiopia are financial institutions, which did not have separate legislation and regulatory framework, which could support for their administration, Operation, Growth, and Sustainability. In addition, they are not allowed to engage in profit making business or asset creation. According to Golden Africa Capacity Center (2010), most SACCOs in the country characterized by weak management, unattractive interest rate, small loan size ,lack of easy access to the savings even when members face emergency for liquidity. This indicates the large demand for loan by members cannot be met due to the small savings of members and shortage of loans from internal sources.

The financial products provided by SACCOs also lacks diversity, flexibility and consistency. It must be a demand driven financial products and services that can play a key role in developing robust sector and enhancing outreach, which in turn leads to greater economies of scale, thereby improving profitability and increasing sustainability. The financial products designed for members should also tie to their cash flows that improve their repayment capacity and allow them to sustain.

Developing Demand driven and member centered broad range of financial products and innovative approaches and projects /programs significantly contribute to improve the capacity of poor rural and urban households in accessing affordable, flexible and quality financial services, which have direct impact in increasing income and improving the welfare of the members. Moreover, the development of appropriate financial products has positive impact on the sustainability of SACCO Unions. In addition to saving and credit service as poor households require to gate micro loan, insurance, remittances and efficient payment system and delivering such products would assist both the primary 
International Journal of Community and Cooperative Studies

Vol.8 No.1, pp.1-8, June 2020

Published by ECRTD- UK

ISSN 2057-2611(Print), ISSN 2057-262X(Online)

SACCOs and poor rural households to be more efficient in transferring risk and allow farmers and poor urban community to trust and the Saccos manage their liquidity.

Weakness in Corporate Governance was also other challenging factor for Savings and credit cooperatives. Most committee members elected by the general assembly to lead the affairs of the societies did not have necessary capacity to bring good corporate governance. That means they did not have the capacity to lead to organize, control and monitor the professional managers to perform their duties and responsibilities accordingly. Thus, weak corporate governance is the main and crucial cause for Unions financial and operational sustainabilties.

Dependency on External financial sources, most Sacco unions in the region have no strategy to mobilize internal source of funds rather dependent to external sources of funds from banks and public Microfinanace institutions. External funds decrease the motivation to mobilize internal deposits and increases the cost of funds. Most savers and loan takers are not convenient for low interest and expensive loan interests. These consequences, the absence of active and vibrant member's participation in deposit and share contribution that challenges their growth and sustainability. External funding does have the advantage of being a resource for longer-term loans, but it should be limited in relation to members' deposits and the internal capacity for managing a larger loan portfolio (Brian, 2005).

Most unions have high operational costs for their services. Increase in operational costs, which attributed to poor financial outreach. These increases also fuel decreases in savings and the number of members, as financial sustainability is already threatened. (Quayes, 2012). Financial sustainability was affected adversely as a result (Hermes et al., 2008).

\section{Operationalization of study variables}

Financial sustainability

According to Paraveen (2009), for an organization to be financially sustainable, it needs to have efficient financial operations, make surplus, maintain adequate liquidity levels, and be able to overcome the challenges of failure. Financial sustainability in this study measured by Financial Sustainability ratios and sustainability indexes, which is the ability of a SACCO to cover all operational and financial costs from its internally generated income (Kinde, 2012).

\section{Definition of Financial Outreach}

The provision of financial services to people who considered the poorest of the poor, and who excluded from the formal banking system defined financial outreach. The goal of financial outreach is to provide high quality financial services to the poor, including receiving savings, issuing loans, and providing social benefits, with the goal of improving the well-being of the poor (Zerai \& Rani, 2012). Financial outreach is classified into two categories: Depth of outreach and breadth of outreach (Louis et al., 201). The focus of this research is on breadth of outreach, which refers to the number of people the institutions have extended credit and has been measured using SACCO savings and numbers of members (Quayes, 2012). 


\section{Breadth of outreach}

As stated above, SACCO savings and numbers of members have been used to measure the breadth of financial outreach. The number of members indicates the popularity of a SACCO, and is considered a measure of its growth (Bwana \& Mwakujonga, 2013). Ceteris paribus, more members result in high loan balances, which translate into more interest income received by the SACCO, thus maintaining financial self-sufficiency. Growth in the capital of a SACCO also result in more savings being mobilized, thus the more members, the higher the level of financial outreach (Wanyama et al., 2009). Savings represent the amount of savings achieved by members of a SACCO (Turtiainen, 2008).African cooperatives try to raise as many savings as possible from their members. This is done in most cases by ensuring that all members make savings on a monthly basis. The more savings a SACCO is able to receive in a given period, the more it is able to issue loans to its members. This increases income earned from interest, which in turn makes a SACCO more financially sustainable, and increases its level of financial outreach (Bwana \& Mwakujonga, 2013).

\section{RESEARCH METHODOLOGY}

Descriptive research design applied for this study, which involved the collection of longitudinal audited financial and administration data for the period of ten years (from 2008 to 2017). In this research, quantitative descriptions of the trends, attitudes of a population were obtained by studying scientifically selected sample. The target population of this research encompassed of SACCO Unions registered in Oromia National Regional State of Ethiopia. Purposive sampling was convenient for collecting primary and secondary data using questionnaires. Unions in the region were chosen because it is the home of $43 \%$ of potential and total number of SACCOs in the country, Amha (2015, FCA (2019). This period was chosen because; it was the time when most Saccos and unions in the region were initiated and in order to gate data for the analysis of the outreach on Financial Sustainability takes long term in nature.

\section{Data Analysis}

Financial outreach of the unions was measured using the number of primary SACCO members and the total volume of savings mobilized. The regression model for financial outreach, as measured by both total members and total savings, is presented as follows:

\section{Where:}

$$
Y=\beta 0+\beta 1 N P M+\beta 2 T S M+e i
$$

$\beta 0$ is the intercept i.e. $Y=\beta 0$ when $x i, 2,3,4, \ldots \ldots \mathrm{k}=0$

$\beta 1, \beta 2, \beta 3, \beta 4 \ldots \beta \mathrm{k}$ are the regression coefficients of the contribution of each measure of the independent variable. $e i=$ Error term

\section{Financial Sustainability Status of Unions}

The sustainability status of SACCO unions sampled for this investigation $52 \%$ of them are less than one while only $48 \%$ of the unions had financial sustainability index more than one. This indicates that most unions were financially not sustainable. 
International Journal of Community and Cooperative Studies

Vol.8 No.1, pp.1-8, June 2020

Published by ECRTD- UK

ISSN 2057-2611(Print), ISSN 2057-262X(Online)

\section{RESULT AND DISCUSSION}

\section{The Number of primary Members Mobilization}

The multiple regression results showed that a significant relationship existed between the growth number of members and financial sustainability. A p-value of 0.009 was reported, which is less than 0.05 , hence there was a significant influence. The present study findings thus indicate that the number of primary members exerts a positive significant influence on financial sustainability of SACCO union's. These findings support those of Rani (2012), Sebhatu, (2011), Amha (2015) who found positive significant relationship between the number of members and financial sustainability. As the number of member's increases, total income also increases in the form of registration fees and interest income from loans issued. As a result, the higher the number of members improves the financial sustainability of Sacco union's.

The regression results show that there is also a significant relationship between total saving mobilized and financial sustainability as measured by financial sustainability. A p-value of 0.041 was reported, which is less than 0.05 . The results were significant at the $5 \% \mathrm{~s} \mathrm{level}$. It indicates that as the volume of savings increased, financial sustainability also increases. These were attributed to more proceeds collected saving from the members. The increased in saving mobilization leads union's more liquid to issue loans to members and to diversify their products.

The more loan issued to member's increases service charges, interest receivables, and surpluses those results more income that improve financial sustainability. Total saving mobilized significantly affect the financial sustainability of Sacco unions. Savings received by Unions are current liabilities to them until they refund it to members in the form of loan. As saving collected are not incomes to them. Hence, it supports the liquidity/cash on hand/ for provision of loans to members on the time needed and support their capital adequacy. Therefore, saving mobilization has significant effect on financial sustainability. By This research, finding thus indicate that total saving volume of the unions exert a significant influence on their financial sustainability. These findings support the previous findings by Sebhatu (2011), Wolday (2015), and Tekle (2015)

\section{CONCLUSIONS}

The objective of the study was to analyze the effect of financial outreach on the financial sustainability of SACCO Unions in Oromia national regional state of Ethiopia. The study adopted quantitative research and involved the collection of longitudinal data for a period of ten years, from 2008 to 2018. Both secondary and primary data were collected for the breadth of outreach perspective, which was measured by both the number of primary members and savings mobilized by unions. This was an indication that the number of primary members and total saving mobilized exerts positive influence on financial sustainability of unions at $5 \%$ significance level. An increase in the number of SACCO members results in increased savings being received, which in turn ensures that more funds are available to members for borrowing and returns from investments. The higher the savings, the more the income received from loans in the form of interest revenues and at the same time meet its expenses from this revenue; such a SACCO is financially sustainable. 
International Journal of Community and Cooperative Studies

Vol.8 No.1, pp.1-8, June 2020

Published by ECRTD- UK

ISSN 2057-2611(Print), ISSN 2057-262X(Online)

\section{Suggested Intervention}

1) The effectiveness and sustainability of Unions depends on the skill of management committee/board members/ elected from the member societies. Competent management committee plays a key role in leading the unions in principle and reducing agency costs by overseeing management's behavior. The cooperative promotion authority should concerned on the skills of elected/candidates going to be elected. Leadership knowledge to understand the financial conditions of the unions. Therefore, we recommend that the concerned authority shall fix an institution (an apex body) that provide sustainable capacity building for management committee on technical and financial knowledge etc.

2) Most SACCO unions follows closed doors approach in members mobilization, they do not have promotion program that attract primary cooperatives for membership. While, banks and microfinances have road show or door-to-door marketing promotion to entice them.

3) The SACCO Unions should reduce their external financial dependency syndrome by amending their bylaws and setting leverage rations in which they can mobilize saving and shares mobilization

4) The Government shall allot Comprehensive financial and operational regulations that guides Effective Corporate Governance for SACCO unions in the region.

\section{Reference}

Adams, R. B., \& Mehran, H. (2012). Bank board of director's structure and Performance: Evidence For large bank holding companies. Journal of Financial Intermediation, 21(2), 243-267.

Amess, K., \& Howcroft, B. (2001). Corporate governance structures and the Comparative Advantage of Credit Unions. Corporate Governance: An International Review, 9(1), 59-65.

Biruk Ayalew Wondem; (January 2015), Rural Saving and Credit Cooperatives Financial Performance, Challenges and Prospects in Rural Financing in East and West Gojjam Zones-Ethiopia.

ETHIOPIA, I. G. O. 1960. Commercial Code of the Empire of Ethiopia of 1960, NegaritGazeta Extraordinary Issue No. 3 of 1960, Addis Ababa.

KIFLE TESFAMARIAM .2011. Management of Savings and Credit Cooperatives from The Perspective of Outreach and Sustainability: Evidence from Southern Tigray of Ethiopia.16-20; available to download at www.iiste.org. .

NEGARITGAZETA, F. 2016a. Cooperative Societies (Amendment) Proclamation Addis Ababa, Ethiopia. NEGARITGAZETA, Cooperative Societies Proclamation No.985/2016, Addis Ababa, Ethiopia.

Federal cooperative agency. 2014. Annual Publication, Vol1, No11; Agricultural Cooperative Sector Development Strategy 2012-2016.

ETHIOPIA, I. G. O. 1960. Commercial Code of the Empire of Ethiopia of 1960, NegaritGazeta Extraordinary Issue No. 3 of 1960, Addis Ababa.

KIFLE TESFAMARIAM .2011. Management of Savings and Credit Cooperatives from the Perspective of Outreach and Sustainability: Evidence from Southern Tigray of Ethiopia.

NEGARITGAZETA, F. 2016b. Cooperative Societies Proclamation No. 985/2016, Addis Ababa, Ethiopia. 
International Journal of Community and Cooperative Studies

Vol.8 No.1, pp.1-8, June 2020

Published by ECRTD- UK

ISSN 2057-2611(Print), ISSN 2057-262X(Online)

SERVICES, P. C. A. I. 2006. Developments in Saving and Credit Cooperatives in Ethiopia: Evolution, Performances, Challenges and Interventions with Particular Emphasis on RUSACCOs (September): Addis Ababa, Ethiopia.

WOLDAY AMHA .2003. Microfinance in Ethiopia: Performance, challenges and the role in poverty reduction. AEMFI, Occasional Paper No. 7. 